\title{
REACTION OF BANANA CULTIVARS TO THE Meloidogyne javanica X Fusarium oxysporum f. sp. cubense COMPLEX ${ }^{1}$
}

\author{
LEANDRO DE SOUZA ROCHA ${ }^{2 *}$, ROBERT FELIX DE SANTANA ${ }^{3}$, ANA CRISTINA FERMINO SOARES ${ }^{3}$, \\ FERNANDO HADDAD ${ }^{2}$
}

\begin{abstract}
The interaction Fusarium oxysporum f. sp. cubense (Foc) x nematode and the genetic variability of Foc are the main problems with potential to affect the use of resistant varieties in the management of the Panama disease. The objective of this work was to evaluate the interaction between Foc and Meloidogyne javanica on the banana of the Prata Anã, Grande Naine and BRS Princesa cultivars. The experiment was conducted in a randomized block design, with six treatments and ten replications, which differed in the inoculation time of each pathogen. Simultaneous inoculation with Foc and M. javanica, inoculation with Foc one week before inoculation with $M$. javanica, and inoculation with $M$. javanica one week before inoculation with Foc. In addition to the controls, Foc isolated, M. javanica isolated, and cultivars without the pathogens. The seedlings were transplanted in 3-liter pots with sterile soil infested with 40 grams of Foc inoculum at the concentration of $1 \times 10^{6} \mathrm{CFU} /$ gram and 1000 eggs and $\mathrm{J} 2$ of M. javanica. At the end of 56 days, the treatments with 'Grande Naine' presented the highest reproduction factors of $M$. javanica. In the 'Prata Anã' no interaction was observed between Foc x M. javanica. The treatments with simultaneous inoculation of the two pathogens, and with Foc a week before, in the 'BRS Princesa', presented the highest external disease indices (DI), which promoted the highest AUDPC. The highest internal DI were observed in the treatments Foc $+\mathrm{Mj}+\mathrm{Grande}$ Naine, Foc $+\mathrm{Mj}+\mathrm{BRS}$ Princesa, $\mathrm{Mj}+\mathrm{Grande}$ Naine+Foc and Foc+BRS Princesa+Mj. The simultaneous presence of $M$. javanica and Foc increases the severity of the Panama disease in Grande Naine and BRS Princesa cultivars.
\end{abstract}

Keywords: Musa spp.. Fusarium wilt. Root-knot nematodes. Interaction. Panama disease.

\section{REAÇÃO DE CULTIVARES DE BANANEIRA AO COMPLEXO Meloidogyne javanica X Fusarium oxysporum f. sp. cubense}

\begin{abstract}
RESUMO - A interação Fusarium oxysporum f. sp. cubense (Foc) x nematoide e a variabilidade genética de Foc são os principais problemas com potencial de afetar o uso de variedades resistentes no manejo do mal-doPanamá. O objetivo do trabalho foi avaliar a interação entre Foc e Meloidogyne javanica sobre as cultivares de bananeiras, Prata Anã, Grande Naine e BRS Princesa. O experimento foi conduzido em DBC, com seis tratamentos e dez repetições, os quais se diferenciaram no tempo de inoculação de cada patógeno. Inoculação simultânea de Foc e $M$. javanica, inoculação de Foc uma semana antes de $M$. javanica e inoculação de $M$. javanica uma semana antes de Foc. Além dos controles, Foc isolado, M. javanica isolado e cultivares sem patógenos. As mudas foram transplantadas em vasos de três litros com solo estéril infestado com 40 gramas de inóculo de Foc na concentração de 1x106UFC/grama e 1000 ovos e J2 de M. javanica. Ao final de 56 dias, os tratamentos em 'Grande Naine' apresentaram os maiores fatores de reprodução de M. javanica. Em 'Prata Anã' não foi observado interação entre Foc x $M$. javanica. Os tratamentos com inoculação simultânea dos dois patógenos e com Foc uma semana antes, em 'BRS Princesa', apresentaram os maiores índices de doença (ID) externos, o que proporcionou as maiores AACPD. Os maiores ID internos foram observados nos tratamentos, Foc $+\mathrm{Mj}+$ Grande Naine, Foc $+\mathrm{Mj}+\mathrm{BRS}$ Princesa, Mj+Grande Naine+Foc e Foc + BRS Princesa+Mj. A presença conjunta de $M$. javanica e Foc aumenta a severidade do mal-do-Panamá nas cultivares Grande Naine e BRS Princesa.
\end{abstract}

Palavras-chaves: Musa spp.. Murcha de Fusarium. Nematoides das galhas. Interação. Mal-do-Panamá.

\footnotetext{
"Corresponding author

${ }^{1}$ Received for publication in $11 / 11 / 2016$; accepted in $09 / 29 / 2017$.

Paper extracted from the doctoral thesis of the first author.

${ }^{2}$ Embrapa Mandioca e Fruticultura, Cruz das Almas, BA, Brazil; leandro.rocha@embrapa.br - ORCID: 0000-0002-8759-4846, fernando.haddad@embrapa.br - ORCID: 0000-0003-0332-3270.

${ }^{3}$ Center for Agrarian, Environmental and Biological Sciences, Universidade Federal do Recôncavo da Bahia, Cruz das Almas, BA, Brazil; robert_fsa10@hotmail.com - ORCID: 0000-0002-0285-8946, ferminosoares@gmail.com - ORCID: 0000-0002-4014-1794.
}

Rev. Caatinga, Mossoró, v. 31, n. 3, p. 572 - 583, jul. - set., 2018 


\section{INTRODUCTION}

Brazilian banana farming stands out among the five largest in the world with an approximate production of 6.8 million tonnes in 464.5 thousand planted hectares (IBGE, 2016). Currently, the Brazilian crop is based on cultivars of the subgroup Prata, with emphasis on 'Prata Anã' (AAB) clone Gorutuba and Catarina. However, crops of the 'Grande Naine', 'Nanica', and 'Nanicão' cultivars that belonging to the Cavendish subgroup, the main export fruit, with approximately $40 \%$ of the world production (PLOETZ, 2015), also stand out in crops of the Southeast and South regions of Brazil.

Cultivated throughout the Brazilian territory, with emphasis on the Northeast and Southeast regions, where $32.7 \%$ of the total volume is produced (IBGE, 2016), the banana crop is affected by constant phytosanitary problems with a wide geographical distribution, with emphasis on fungi and nematodes. However, for the banana crop, the major phytosanitary problems are due to fungi causing Yellow Sigatoka (Mycosphaerella musicola), Black Sigatoka (Mycosphaerella fijiensis) and Panama disease (Fusarium oxysporum f.sp. cubense, Foc). In the main regions with irrigated banana crops in Brazil, the greatest losses in production are related to Panama disease, which are aggravated by the presence of nematodes, mainly from the Meloidogyne genus, present in the main banana producing regions. Cofcewicz et al. (2004) found Meloidogyne javanica and Meloidogyne incognita in 61.7 and $32.2 \%$, respectively, in soil samples from banana crops of the states of Pernambuco, Bahia, Minas Gerais, São Paulo, and Rio Grande do Sul, Brazil.

Genetic resistance is the most effective and sustainable management option for Panama disease (STOVER; BUDDENHAGEN, 1986; JONES, 2000; PLOETZ; PEGG 2000; HWANG; KO, 2004). However, the use of resistant varieties in the control of the disease is limited due to the genetic variability of the pathogen (variants) and the overcoming of resistance caused by the nematode infection. The interaction between nematode and Foc in banana requires more detailed information and studies to elucidate the main factors involved in this complex. And, therefore, to plan a more efficient management system for this pathosystem. The objective of this work was to evaluate the interaction between Foc and $M$. javanica on the main banana cultivars planted in Brazil, 'Prata Anã' and 'Grande Naine', and a new banana cultivar type Silk, 'BRS Princesa'.

\section{MATERIAL AND METHODS}

Conduction of the experiment, and available
material
The experiment was conducted in the greenhouse of the Embrapa-Brazilian Agricultural Research Corporation; Embrapa Mandioca e Fruticultura - in Cruz das Almas BA, Brazil, during the months of June and July, in which temperatures ranging from $20.2^{\circ} \mathrm{C}$ to $27.3^{\circ} \mathrm{C}$ were observed, with a mean of $23.0^{\circ} \mathrm{C}$ (Cruz das Almas Conventional Meteorological Station).

In the experiment the Foc 218A isolate, obtained in cultivar Nanica, was used due to its greater aggressiveness, observed in preliminary trials, belonging to the Biological Collection of $F$. oxysporum f. sp cubense of the Plant Pathology Laboratory of the Embrapa Cassava \& Fruits. The 218A isolate was identified by morphological characters and molecular characterization from the sequencing of the gene of elongation factor $1 \alpha$ (tef- $1 \alpha)$.

It was used as the nematode inoculum, a pure population of $M$. javanica from a banana tree, and multiplied and maintained in a tomato tree (Lycopersicon esculentum Mill) of the Santa Cruz Kada cultivar, in a greenhouse of the Embrapa Cassava \& Fruits. The identification of the nematode species was carried out by examining the perineal region of females (EISENBACK, 1985; HIRSCHMANN, 1985), and by the phenotype of the isozyme esterase (CARNEIRO; ALMEIDA, 2001; KUNIEDA DE ALONSO et al., 1995; ALFENAS; PETERS; PASSADOR, 1991; ESBENSHADE; TRIANTAPHYLLOU 1990; 1985).

It was used micropropagated banana seedlings of the Prata Anã cultivar (AAB Group), which is susceptible to Panama disease and moderately resistant to $M$. javanica, Grande Naine cultivar (AAA Group), which is resistant to Panama disease and susceptible to $M$. javanica, and BRS Princesa cultivar (AAAB Group), which is quantitatively resistant to Panama disease and moderately resistant to $M$. javanica (CORDEIRO; MATOS; HADDAD, 2016; COSTA et al., 2016; COSTA et al., 2015; COFCEWICZ et al., 2004).

\section{Obtaining the $F$. oxysporum f. sp. cubense inoculum}

Foc 218A isolate was amplified in Petri dishes with PDA culture medium for 10 days in a BOD chamber at $25^{\circ} \mathrm{C}$ and 12 -hour photoperiod. After this period, 10 mycelial discs with diameter of $5 \mathrm{~mm}$ from the Foc colony were transferred to a sand-cornmeal medium in plastic bags $(250 \mathrm{~g}$ of washed sand $+50 \mathrm{~g}$ of cornmeal $+50 \mathrm{ml}$ of distilled sterilized water, subjected to three autoclaving cycles, with 24-hour intervals between them, at $121^{\circ} \mathrm{C}$ for 20 minutes). The bags were then placed in a BOD at $25^{\circ} \mathrm{C}$ and 12 -hour photoperiod, where they remained for 30 days, to favor the chlamydospore production. Prior to use in soil infestation, the inoculum was quantified by serial dilution and 
counting of colony forming units (CFU). The dilution consisted of placing 10 grams of inoculum in $90 \mathrm{~mL}$ of distilled sterilized water, and then $1 \mathrm{~mL}$ was withdrawn from the first suspension and diluted in $9 \mathrm{~mL}$ of distilled sterilized water, refolding the process to the dilution of $10^{-5}$. From the last dilution, $200 \mu \mathrm{L}$ were withdrawn, which were streaked with the aid of a Drigalski spatula in a Petri dish containing PDA culture medium, in three replications. Then the plates were incubated in BOD at $25^{\circ} \mathrm{C} 12$-hour photoperiod and, after 48 hours, it was carried out the counting of CFU. The final inoculum was adjusted to $10^{6} \mathrm{CFU} /$ gram of substrate.

\section{Obtaining the M. javanica inoculum}

The population of $M$. javanica used in the work was multiplied in a tomato tree of the Santa Cruz Kada cultivar, and after 60 days, it was performed the extraction of eggs and second-stage juveniles (J2), according to the Hussey and Barker methodology, modified by Boneti and Ferraz (1981) and, with the aid of Peters's chamber, it was adjusted the suspension to 1.000 eggs and $\mathrm{J} 2 / \mathrm{mL}$ under an optical microscope.

\section{Plant material}

For the assembly of the experiment it was used micropropagated banana seedlings of the Grande Naine, Prata Anã and BRS Princesa cultivars. Before being transplanted, the seedlings produced in vitro were planted in $180-\mathrm{cm}^{3}$ tubes containing plant substrate and acclimatized in a greenhouse under shade screen with 50\% light interception for a period of 60 days at an average temperature of $25^{\circ} \mathrm{C}$.

\section{Experiment implementation}

The acclimatized seedlings of the banana cultivars were transplanted in 3-liter pots containing sterilized mixture of soil $(50 \%)$, manure $(25 \%)$ commercial substrate $(15 \%)$, and coconut fiber $(10 \%)$. This mixture was subjected to three cycles of autoclaving with 24-hour intervals between them, at $121^{\circ} \mathrm{C}$ for 20 minutes. After the planting of the seedlings, the infestation of the soil was started with inocula of Foc and $M$. javanica, according each treatment: Foc and $M$. javanica inoculated at the same time (Foc $+\mathrm{Mj}+$ Cultivar); Foc inoculated one week before of the inoculation with $M$. javanica (Foc + Cultivar $+\mathrm{Mj}$ ), and Foc inoculated one week after the inoculation with $M$. javanica $(\mathrm{Mj}+$ Cultivar + Foc). For the inoculation, it was deposited 40 grams of inoculum of Foc, and $1 \mathrm{~mL}$ of the suspension containing 1000 eggs and $\mathrm{J} 2$ of $M$. javanica, which was distributed in three holes around the plants. The control treatments were: inoculation of plants with 40 grams of sand-cornmeal without the Foc plus $1 \mathrm{~mL}$ of water without nematode (Cultivar), isolated inoculation of Foc (Foc + Cultivar) and isolated inoculation of $M$. javanica containing the same level of inoculum previously described $(\mathrm{Mj}+$ Cultivar). The experiment was conducted in a randomized block design, with six treatments per cultivar, and ten replications. The plants were kept for 56 days in a greenhouse, being irrigated daily. Each of the three cultivars, Grande Naine, Prata Anã and BRS Princesa, were evaluated in independent experiments.

The severity of the Panama malaria (external symptoms) was evaluated from the first week after planting (DAP), at intervals of seven days for 56 days, following the five-grade scale proposed by Dita, Pérez Vicente and Martinez De La Parte (2014), wherein $1=$ no symptoms; $2=$ initial yellowing of old leaves; $3=$ yellowing of old leaves with initial discoloration on young leaves; $4=$ all leaves with intense yellowing; and $5=$ dead plant. Evaluation of rhizome discoloration was carried out throughout the experiment, after the death of the seedlings, and at the end of the 56 DAP, using the grade scale described by Cordeiro et al. (1993), which varies from 0 to 5 , being $0=-$ rhizoma completely healthy; $1=$ isolated infection points; $2=$ infection reaching up to $1 / 3$ of the ring (region of root formation, where the infection is established in the rhizome); $3=$ infection reaching $1 / 3$ to $2 / 3$ of the ring; $4=$ infection reaching more than $2 / 3$ of the ring, and $5=$ generalized infection. From these grades, it was calculated the disease indices (DI) for external and internal symptoms, using the Mckinney's formula (MCKINNEY, 1923), in which DI $(\%)=100 . \Sigma[($ f.v $) /($ n.x $)]$, wherein DI $=$ disease index; $\mathrm{f}=$ number of plants with the same grade; $\mathrm{v}=$ observed grade; $\mathrm{n}=$ number of total plants evaluated, and $\mathrm{x}=$ highest grade in the scale. For the development of the disease over time (external symptoms), it was calculated the area under the disease progress curve.

The evaluation of nematode was performed using the number of eggs plus number of second-stage juveniles (J2) per root system, number of $\mathrm{J} 2$ in the soil, and by reproduction factor given by the formula $\mathrm{RF}=\mathrm{Pf} / \mathrm{Pi}$, wherein $\mathrm{RF}=$ reproduction factor; $\mathrm{Pf}=$ final nematode population (root and soil), and $\mathrm{Pi}=$ initial population (OOSTENBRINK, 1966). After extraction, according to Boneti and Ferraz (1981), the eggs were quantified in a Peters's chamber under an optical microscope. The number of $\mathrm{J} 2$ of $M$. javanica present in the soil was obtained after extraction in $200 \mathrm{~cm}^{3}$ of soil, according to Jenkins (1964) and counting in a Peters's chamber under an optical microscope.

The reaction of banana cultivars to $M$. javanica was determined by the criteria of Moura and Régis (1987), which consider the reduction of the reproductive factor 
$(\mathrm{RRF}=($ standard $\mathrm{RF}-\mathrm{RF}$ treatment $) /$ standard $\mathrm{RF}))$ of the nematode in relation to the most susceptible host evaluated. According to Moura and Régis (1987), plants that provide RFR of nematode of $100 \%$ are classified as highly resistant or immune (HR or I), 96 to $99 \%$ resistant (R), 76 to $95 \%$ moderately resistant (MR), 51 to $75 \%$ slight resistant (SR), 26 to $50 \%$ susceptible (S), and $\leq 25 \%$ are classified as highly susceptible (HS). For the RRF calculation, the highest mean value of RF was taken as the susceptibility standard, considered as $0 \%$ reduction.

The calculations referring to the statistical analysis were performed using the software Sisvar (FERREIRA, 2011). The data were subjected to analysis of variance, and means were compared by the Scott-Knott test, at 5\% probability.

\section{RESULTS AND DISCUSSION}

The largest reproduction factor (RF) of $M$. javanica was observed in isolated inoculation of the nematode in plants of the Grande Naine cultivar (Table 1). Compared to other cultivars, Prata Anã and BRS Princesa, with inoculation only with $M$. javanica, the RF was 3.64 and 4.36 fold higher, respectively. Independently of the inoculation before, after or simultaneously with M. javanica and Foc, the highest RF were observed in the treatments with the Grande Naine cultivar. In the 'BRS Princesa' inoculated with the two pathogens, regardless of the alternation, it was observed the lower RF of $M$. javanica. In the Prata Anã cultivar, the isolated inoculation with $M$. javanica promoted the same RF of the three treatments with simultaneous inoculation, with variation of 7.13 to 7.66 .

Table 1. Mean values of the reproduction factor (RF) and percentage of reduction of the reproduction factor (RRF) of the nematode in banana cultivars with simultaneous and alternate inoculation with Meloidogyne javanica and Fusarium oxysporum f. sp. cubense (Foc).

\begin{tabular}{llc}
\hline Treatments & RF & RRF (\%) \\
\hline Foc + BRS Princesa & $0 \mathrm{a}$ & - \\
BRS Princesa & $0 \mathrm{a}$ & - \\
Prata Anã & $0 \mathrm{a}$ & - \\
Grande Naine & $0 \mathrm{a}$ & - \\
Foc + Grande Naine & $0 \mathrm{a}$ & - \\
Foc + Prata Anã & $0 \mathrm{a}$ & 99.93 \\
Foc + BRS Princesa + Mj & $0.04 \mathrm{a}$ & 99.74 \\
Foc + Mj + BRS Princesa & $0.08 \mathrm{a}$ & 94.4 \\
$\mathrm{Mj}+$ BRS Princesa + Foc & $1.56 \mathrm{a}$ & 77.07 \\
$\mathrm{Mj}+$ BRS Princesa & $6.38 \mathrm{~b}$ & 74.38 \\
Foc + Mj + Prata Anã & $7.13 \mathrm{~b}$ & 74.01 \\
$\mathrm{Mj}+$ Prata Anã + Foc & $7.23 \mathrm{~b}$ & 72.58 \\
$\mathrm{Mj}+$ Prata Anã & $7.63 \mathrm{~b}$ & 72.47 \\
Foc + Prata Anã + Mj & $7.66 \mathrm{~b}$ & 61.91 \\
Foc + Grande Naine + Mj & $10.60 \mathrm{c}$ & 47.67 \\
Mj + Grande Naine + Foc & $14.56 \mathrm{~d}$ & 46.44 \\
Foc + Mj + Grande Naine & $14.90 \mathrm{~d}$ & 0.00 \\
$\mathrm{Mj}+$ Grande Naine & $27.82 \mathrm{e}$ & \\
\hline $\mathrm{CV}$ (\%) & 25.39 & - \\
\hline
\end{tabular}

Means followed by the same letter do not differ significantly by the Scott-Knott test at $5 \%$ probability of error.

$\mathrm{RRF}=$ Reduction of Reproduction Factor $=($ standard $\mathrm{RF}-\mathrm{RF}$ treatment $) /$ standard $\mathrm{RF}$. 
In the Grande Naine in BRS Princesa cultivars, the fungus presence also affected the nematode-plant interaction, and reduced the $M$. javanica reproduction. Probably, the Foc presence changed the production and release of root exudates, which are essential for the attraction of the nematode and identification of the host plant, and there was competition for infection and feeding sites.

Ribeiro et al. (2012) correlated the negative effect of Foc on $M$. javanica reproduction to competition in the infection or feeding sites, since both are vascular parasites. Frequent release of toxins or hormone-like compounds by $F$. oxyporum after penetration alters the host plant physiology for its benefit (KNOGGE, 1996). These changes can affect the formation of giant cells or their maintenance, reducing the nematode population (RIBEIRO et al., 2012). A decreased nematode reproduction due to the fungus was also found in a $M$. hapla-alfalfa pathosystem previously infected with $F$. oxysporum f. sp. medicaginis (GRIFFIN; THYR, 1988).
In the classification of resistance of the cultivars in relation to the nematode, Grande Naine inoculated with only $M$. javanica presented the highest RRF 27.82, being classified as highly susceptible to $M$. javanica (Table 2). The Prata Anã and BRS Princesa cultivars inoculated only with $M$. javanica were classified as slight resistant and moderately resistant, respectively, with RRF of 72.58 and $77.07 \%$. The inoculation with Foc did not affected the RF of the $M$. javanica in the Prata-Anã cultivar. However, when the Foc was inoculated at the same time as $M$. javanica or one week after the inoculation with the nematode, the 'Grande Naine' behaved as susceptible, and as slight resistant when inoculated with Foc one week before the inoculation with $M$. javanica. In the 'BRS Princesa', the fungus presence, inoculated simultaneously or one week before the $M$. javanica, caused the cultivar to behave as resistant. The highest susceptibility of the Grande Naine cultivar to the root-knot nematode found in this work corroborate the results of Tenente et al. (2008).

Table 2. Behavior of banana cultivars to the nematode, evaluated at 56 days after simultaneous and alternate inoculation with Meloidogyne javanica and Fusarium oxysporum f. sp. cubense (Foc).

\begin{tabular}{lc}
\hline Treatments & Behavior* \\
\hline Foc + BRS Princesa + Mj & Resistant \\
Foc + Mj + BRS Princesa & Resistant \\
$M j+$ BRS Princesa+Foc & Moderately Resistant \\
$M j+$ BRS Princesa & Moderately Resistant \\
Foc + Mj + Prata Anã & Slight Resistant \\
$M j+$ Prata Anã + Foc & Slight Resistant \\
$M j+$ Prata Anã & Slight Resistant \\
Foc + Prata Anã + Mj & Slight Resistant \\
Foc + Grande Naine $+M j$ & Slight Resistant \\
$M j+$ Grande Naine + Foc & Susceptible \\
Foc + Mj + Grande Naine & Susceptible \\
$M j+$ Grande Naine & Highly Susceptible \\
\hline
\end{tabular}

*Behavior according to Moura and Régis (1987).

In the Grande Naine cultivar, the first external symptoms of Panama disease were observed at seven days after planting in the isolated inoculation with Foc, simultaneous with M. javanica, and Foc inoculated one week before the $M$. javanica (Figure 1A). However, the isolated inoculation with Foc, and at the same time with M. javanica promoted an average increase of the DI above $2.7 \%$ per day in the first three weeks of evaluation, which provided the highest AUDPC of this treatments at 56 days after plating (Figure 1). In the inoculation of 'Grande
Naine' seedlings with Foc one week before the $M$. javanica, the low disease index observed throughout the experiment provided 6-fold less AUDPC than the AUDPC of the treatments with isolated inoculation with Foc, and simultaneous with $M$. javanica (Figure 1). In the treatments 'Grande Naine' without inoculation with Foc and $M$. javanica, 'Grande Naine' inoculated with $M$. javanica, and 'Grande Naine' inoculated with $M$. javanica one week before the Foc, it was observed no external symptoms of Panama disease (Figure 1A). 


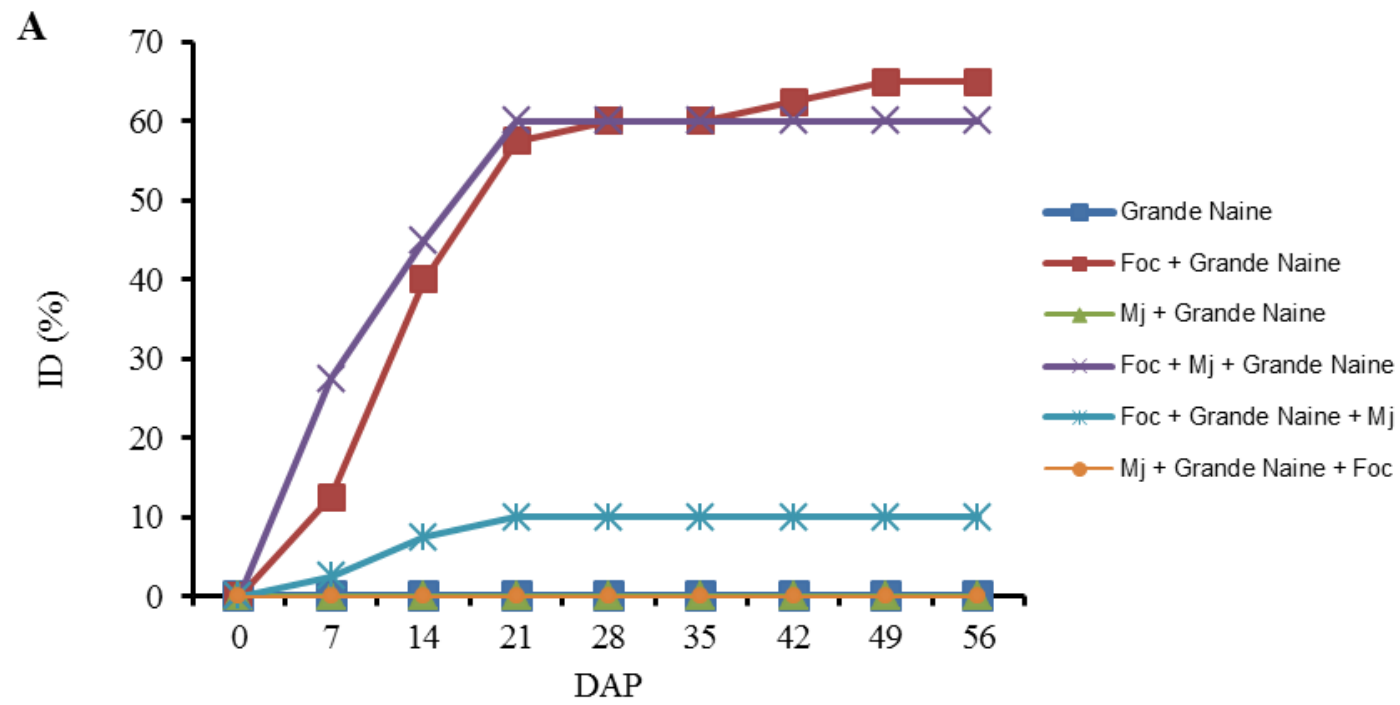

B

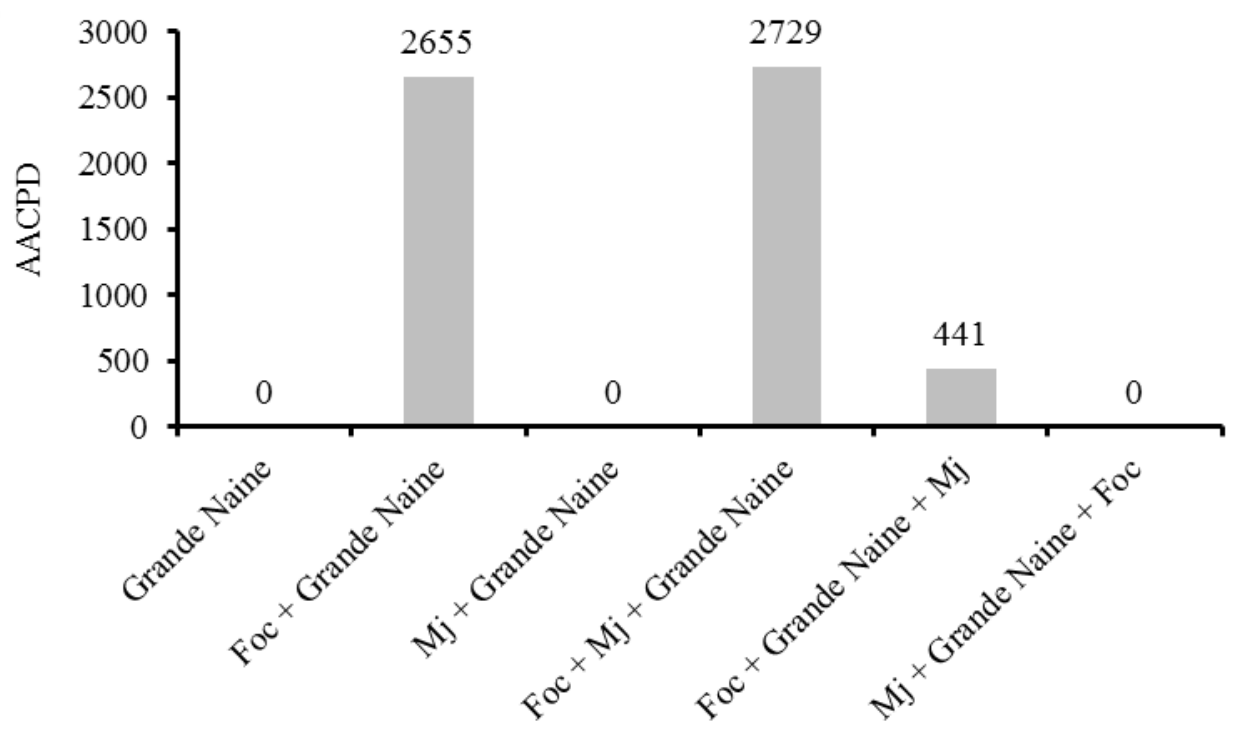

Figure 1. Area under the disease progress curve (AUDPC) calculated from the disease index (DI) for external symptoms of Panama disease in banana seedlings of the 'Grande Naine' cultivar grown in greenhouse for 56 days. A - Disease progress curve expressed in percentage of the disease index; B - AUDPC calculated from the disease indices.

The absence of external symptoms in 'Grande Naine' inoculated with Foc one week after the infestation of the soil with M. javanica, despite of the high disease index observed at 56 DAP, is explained by the increased incubation period of the fungus. Probably, this occurred due to the competition with the nematode, which had already penetrated and established its feeding site, hindering the fungus colonization, which occurred probably later than in the other treatments. However, openings in the root system, and possible changes in cellular metabolism, and host gene expression caused by M. javanica, and the Foc isolate aggressiveness promoted a significant increase in the internal DI at the end of 56 days.
In the 'BRS Princesa', at seven days after planting, it was observed the first Panamá disease symptoms in the isolated inoculation with Foc, at the same time with $M$. javanica, and Foc inoculated one week before the M. javanica (Figure 2A). During the 56 days, treatments with simultaneous inoculation with the two pathogens, and with Foc a week before, in the 'BRS Princesa' seedlings, presented the highest disease indices, which provided the highest AUDPC (Figure 2). The Control treatments 'BRS Princesa' without inoculation with the pathogens, and 'BRS Princesa' inoculated with $M$. javanica did not present Panama disease symptoms (Figure 2A). 
A

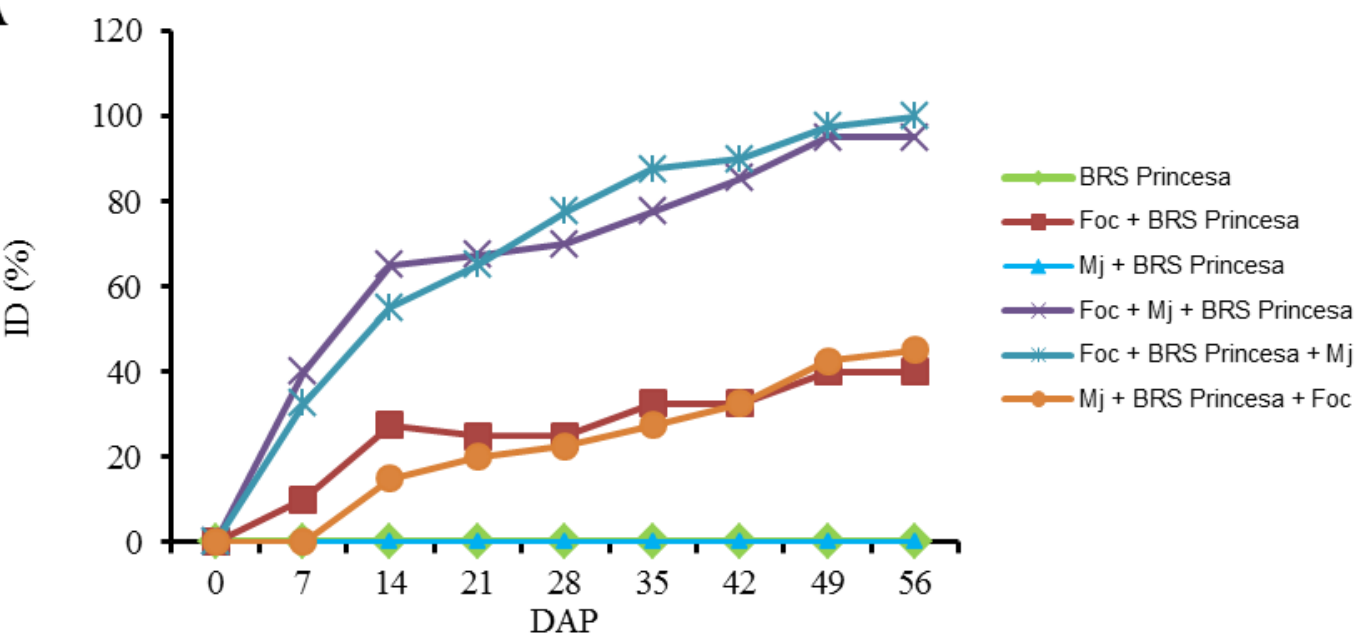

B

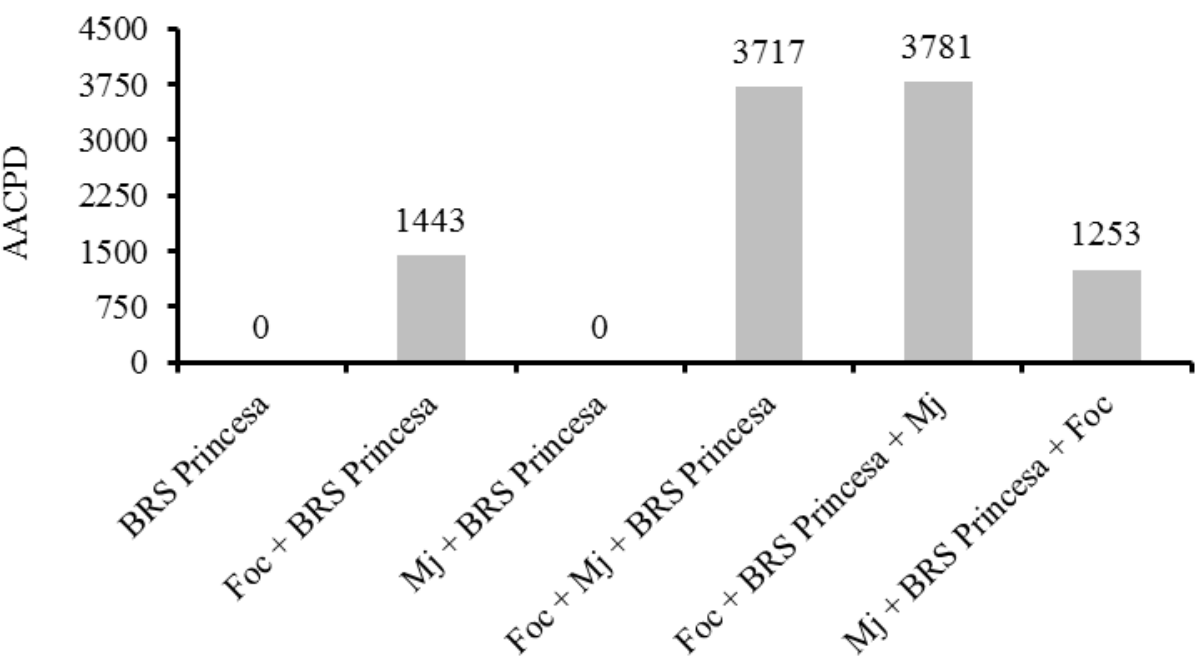

Figure 2. Area under the disease progress curve (AUDPC) calculated from the disease index (DI) for external symptoms of Panama disease in banana seedlings of the 'BRS Princesa' cultivar grown in greenhouse for 56 days. A - Disease progress curve expressed in percentage of the disease index; B - AUDPC calculated from the disease indices.

In the Prata Anã cultivar, all treatments with Foc showed Panama disease symptoms at fourteenth day, except the treatment with inoculation with Foc one week before the $M$. javanica, in which the first Panama disease symptoms were observed at the twenty-first day (Figure 3A). The treatment 'Prata Anã' inoculated with $M$. javanica one week before the Foc presented the highest disease indices during the experiment, which promoted the highest AUDPC (Figure 3). The other treatments inoculated with Foc had the same disease index 56 days after planting, but different AUDPC because of the different indices observed in the evaluations performed from 7 to 49 days after planting (Figure 3). No Panama disease symptoms were observed in treatments without Foc inoculation (Figure 3A).

In the Grande Naine cultivar, the highest disease indices related to internal Foc symptoms were observed in treatments with simultaneous inoculation, and previous inoculation of the nematode (Figure 4). In these treatments, the average increase in disease index was $23 \%$ and $29 \%$, compared to the treatments, 'Grande Naine' inoculated only with Foc, and Foc inoculated one week before the nematode, respectively. 

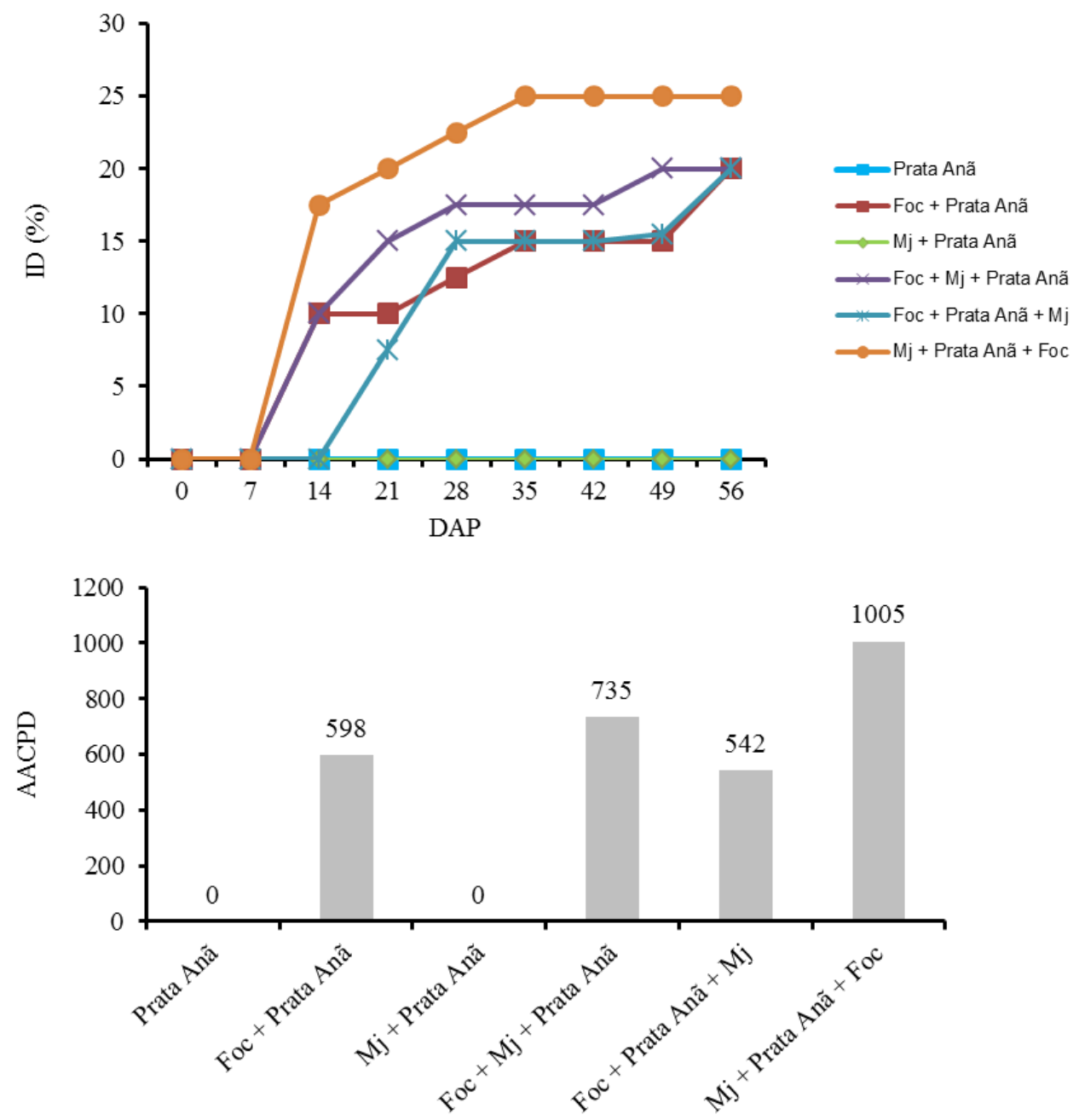

Figure 3. Area under the disease progress curve (AUDPC) calculated from the disease index (DI) for external symptoms of Panama disease in banana seedlings of the 'Prata Anã' cultivar grown in greenhouse for 56 days. A - Disease progress curve expressed in percentage of the disease index; B - AUDPC calculated from the disease indices.

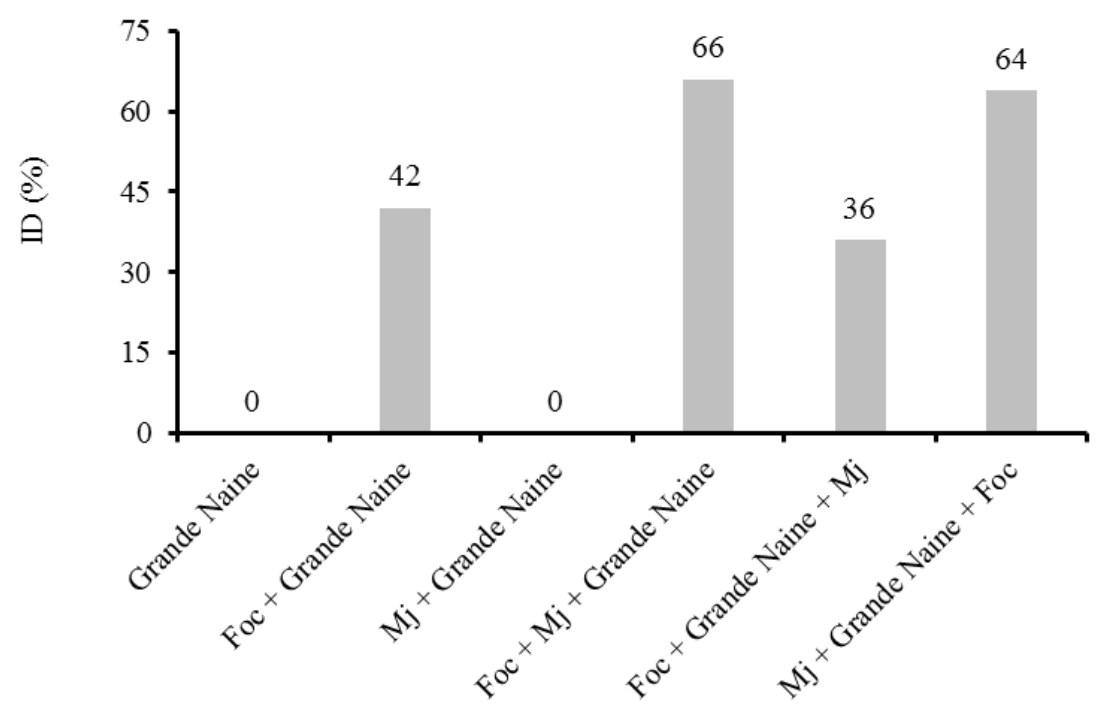

Figure 4. Disease indices (DI) calculated from Panama disease internal symptoms in banana seedlings of the 'Grande Naine' cultivar at 56 DAP in a greenhouse. 
The reduction of internal DI in the 'Grande Naine' inoculated with Foc one week before the nematode, compared to the other treatments with 'Grande Naine' containing nematode, probably occurred due to factors related to the resistance of the host. In response to the initial infection by Foc, the host plant begins a process of production of tyloses, gums and gels in the xylem cavity in the attempt to stop the pathogen progression. In addition, in resistant cultivar, these products are produced earlier and more quickly than in the susceptible ones, and thus, the systemic infection in the stem is blocked (PLOETZ, 2015). Therefore, although the nematode favored the Foc penetration, the host plant had already established barriers to prevent the disease internal progress. In this sense, the DI of this treatment could be more conditioned by isolate aggressiveness than by Foc $\mathrm{x} M$. javanica interaction.

In banana seedlings of 'BRS Princesa', the inoculation with Foc and $M$. javanica at the same time presented the highest disease index, followed by inoculation with Foc before the $M$. javanica. The treatments with isolated inoculation with Foc, and with Foc after the $M$. javanica reduced the disease index by $24 \%$ and $36 \%$, respectively, compared to the treatment with simultaneous inoculation of the pathogens (Figure 5).

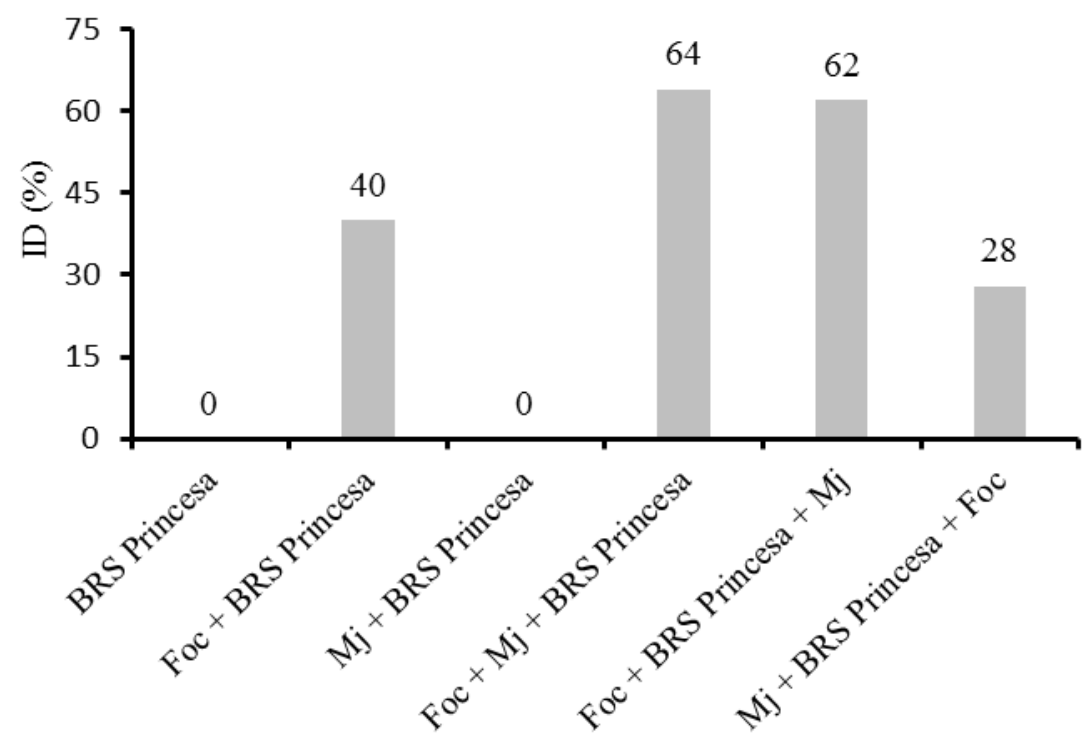

Figure 5. Disease indices (DI) calculated from Panama disease internal symptoms in banana seedlings of the 'BRS Princesa' cultivar at $56 \mathrm{DAP}$ in a greenhouse.

In the BRS Princesa cultivar, the nematode, and the aggressiveness of the Foc isolate promoted an increase in the Panama disease severity. Due to its quantitative resistance (COSTA et al., 2015), the Foc presence in this cultivar probably induced the formation of barriers, but did not prevent the internal colonization by the fungus, which after the inoculation with the nematode increased its severity due to the low competition capacity of the host. However, the smallest DI in the treatment in which the fungus was inoculated one week after the nematode probably occurred due to the competition for space and nutrients between both pathogens, since the nematode had already established its space and feeding site. Since the 'BRS Princesa' is less susceptible to the $M$. javanica than the 'Grande Naine', there was lower interference of the nematode on the final disease index, which was dependent on the fungus aggressiveness.

The disease indices for internal symptoms in the 'Prata Anã' cultivar presented the same pattern observed for external symptoms, and no effects of the nematode in the Foc aggressiveness were found. The difference between the means of the treatments with inoculation with both pathogens and the control (only Foc) was only 2.6\% (Figure 6).

In the 'Prata Anã' cultivar, no competition between the pathogens was observed, and the $M$. javanica reproduction and Foc severity were normal, compared to the control inoculated only with Foc or with $M$. javanica. Probably, there was no competition between both pathogens for infection and/or feeding sites. The possible changes in gene expression and plant cell metabolism influenced by the nematode did not interfered in the fungus severity, and there was no effect of toxins or hormone-like compounds produced by the Foc over the nematode parasitism process. Similar results were found in the Meloidogyne incognita race $3 \mathrm{x}$ Fusarium solani interaction on passionfruit of the Maguari cultivar, which is resistant to the nematode (FISCHER et al., 2010). 


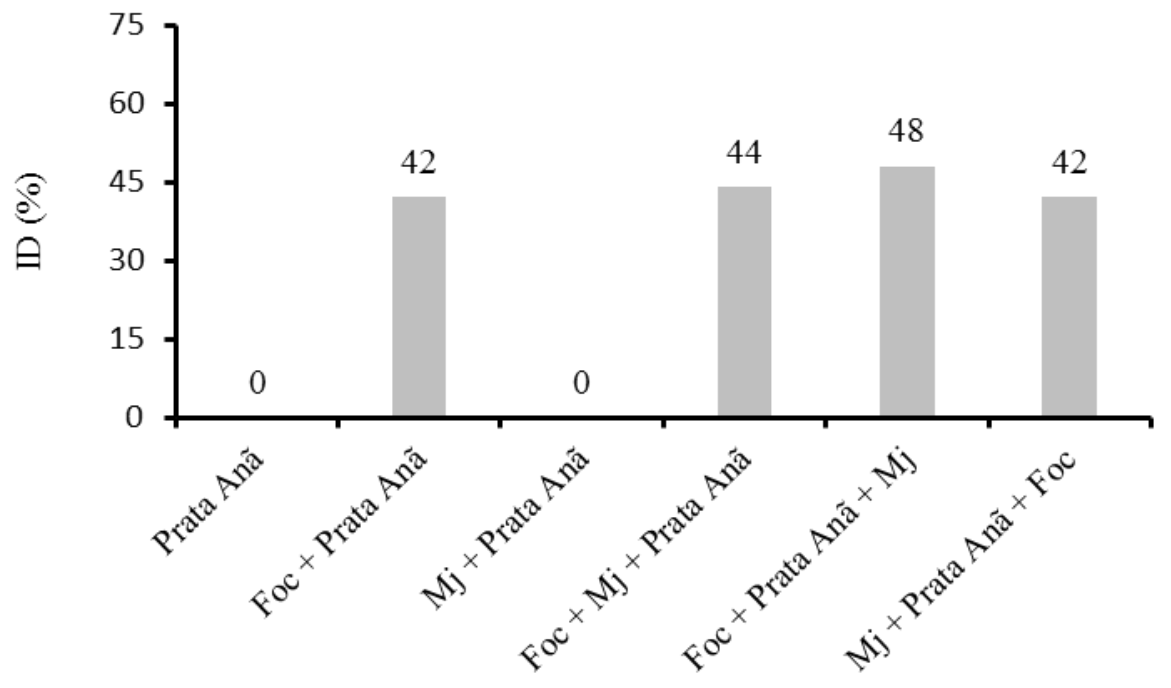

Figure 6. Disease indices (DI) calculated from Panama disease internal symptoms in banana seedlings of the 'Prata Anã' cultivar at $56 \mathrm{DAP}$ in a greenhouse.

Intensification of $F$. oxysporum severity, observed by Silva and Pereira (2008) in simultaneous inoculation with $M$. incognita in ochro, with significant increase of dead plants, also was found in the simultaneous interaction of $M$. javanica and Foc in the Grande Naine and BRS Princesa cultivars. Result equally reported by Simão et al. (2010), when they evaluated the $F$. oxyporum x $M$. javanica complex in cultivars and lines of common bean.

The fact of the Grande Naine and BRS Princesa cultivars, resistant to Foc, had the same DI than the 'Prata Anã' in the isolated presence of the fungus, can be explained by the aggressiveness of the isolate. This isolate was obtained from Panama disease symptoms in Nanica cultivar planted in Eldorado SP, Brazil, and there is a report of great genetic variability among isolates of Foc obtained from different regions of Brazil (COSTA et al., 2015). This can be related to the evolutionary potential of Foc, which promotes the appearance of new more aggressive variants, with ability of infecting resistant cultivars. Despite 'BRS Princesa' is considered with a high resistance level, Costa et al. (2015) also reported infection with more aggressive Foc isolates, which was considered by these authors as variants. These authors also report that despite the absence of information on Panama disease affecting 'BRS Princesa' at field, preliminary tests indicated that its resistance is quantitative. Thus, the presence of more aggressive isolates or high-pressure of initial inoculum can cause infection in the 'BRS Princesa' cultivar. It is important to emphasize that there are no reports of BRS Princesa infected by Foc at field, denoting its capacity to be used in areas with history of this disease.

The Foc fungus and $M$. javanica nematode are phytopathogens that penetrate young roots in the ring region and elongation zone of plants (CAMPOS et al., 2011; BRANDES, 1919). The penetration of
Foc into banana root system occurs through mechanical action of hyphae and/or injuries caused mainly by nematodes, such as the $M$. javanica. Besides facilitate the Foc penetration through the injuries caused in the root, the nematodes predispose physiologically the host plant to fungus infection, affecting directly in the Foc severity. In the infection process in the host, sedentary phytonematode alters the expression of genes and metabolism of plant cells due to the production and secretion of parasitism proteins (DAVIS; HUSSEY; BAUM, 2004; HUSSEY; DAVIS; BAUM, 2002; DAVIS et al., 2000).

Based on the results obtained, it is suggested that in banana cultivars, the Foc and $M$. javanica interaction involve changes in cellular, molecular, and metabolic processes in the plant, that are more complex than only the process of opening wounds on the roots. However, for the particularization of this processes, the systemic biology of this pathosystem must be prioritized in new studies.

It was observed no significant differences between the treatments in the means of height and diameter of the three varieties (data not shown)

\section{CONCLUSIONS}

In the Prata Anã cutivar, the $M$. javanica and $F$. oxysporum f. sp. cubense interaction does not interfere in the nematode reproduction and Foc severity. The simultaneous presence of $M$. javanica and Foc increases the Panama disease severity and reduces the nematode reproduction in the Grande Naine and BRS Princesa cultivars. The Grande Naine cultivar presents higher susceptibility to the $M$. javanica than the 'Prata Anã' and 'BRS Princesa' cultivars. 


\section{ACKNOWLEDGMENTS}

The authors thank the Brazilian Agricultural Research Corporation (EMBRAPA) for financing this project.

\section{REFERENCES}

ALFENAS, A. C.; PETERS, W.; PASSADOR, G. C. Eletroforese de proteínas e isoenzimas de fungos e essências florestais. 1. ed. Viçosa, MG: UFV, 1991. $242 \mathrm{p}$.

BONETI, J. I. S.; FERRAZ, S. Modificação do método de Hussey e Barker para extração de ovos de Meloidogyne exigua de cafeeiro. Fitopatologia Brasileira, Brasília, v. 6, n. 3, p. 553, 1981.

BRANDES, E. W. Banana wilt. Phytopathology, Saint Paul, v. 9, s/n., p. 339-389, 1919.

CAMPOS, H. D. et al. Atração e penetração de Meloidogyne javanica e Heterodera glycines em raízes excisadas de soja. Ciencia Rural, Santa Maria, v. 41, n. 9, p. 1496-1502, 2011.

CARNEIRO, M. D. G.; ALMEIDA, M. R. A. Técnica de eletroforese usada no estudo de enzimas dos nematoides de galhas para identificação de espécies. Nematologia Brasileira, Brasília, v. 25, n. 1, p. 35-44, 2001.

COFCEWICZ, E. T. et al. Reação de cultivares de bananeira a diferentes espécies de nematóides das galhas. Nematologia Brasileira, Brasília, v. 28, n. 1, p. 11-22, 2004.

CORDEIRO, Z. J. M.; MATOS, A. P.; HADDAD, F. Doenças Fúngicas e bacterianas. In: FERREIRA, C. F. et al. (Eds.). O agronegócio da banana. Brasília: Embrapa, 2016. v. 1, cap. 16, p. 545-575.

CORDEIRO, Z. J. M. et al. Avaliação de resistência ao mal-do-Panamá em híbridos tetraploides de bananeira. Fitopatologia Brasileira, Brasília, v. 18, n. 4 , p. $478-483,1993$.

COSTA, D. C. et al. Nematoides. In: FERREIRA, C. F. et al. (Eds.). O agronogócio da banana. Brasília: Embrapa, 2016. v. 1, cap. 15, p. 505-543.

COSTA, S. N. et al. Genetic structure of Fusarium oxysporum f. sp. cubense in different regions from Brazil. Plant Pathology, London, v. 64, n. 1, p. $137-$ 146, 2015.

DAVIS, E. L.; HUSSEY, R. S.; BAUM, T. J. Getting to the roots of parasitism by nematodes.
Trends in Parasitology, Cambridge, v. 20, n. 3, p. 134-141, 2004.

DAVIS, E. L. et al. Nematode Parasitism Genes. Annual Review of Phytopathology, Palo Alto, v. 38, s/n., p. 365-396, 2000.

DITA, M. A.; PÉREZ VICENTE, L.; MARTINEZ DE LA PARTE, E. Inoculation of Fusarium oxysporum f. sp. cubense causal agent of fusarium wilt in banana. In: PÉREZ-VICENTE, L.; DITA, M. A.; MARTINEZ-DE LA PARTE, E. (Eds.). Technical Manual: Prevention and diagnostic of Fusarium Wilt of banana caused by Fusarium oxysporum f. sp. cubense Tropical Race 4 (TR4). Trinidad and Tobago: FAO/CARDI, 2014. v. 1, p. 55 -58 .

EISENBACK, J. D. Diagnostic characters useful in the identification of the four most common species of root-knot nematodes (Meloidogyne spp.). In: SASSER, J. N; CARTER, C. C. (Eds.). An advanced treatise on Meloidogyne. Raleigh: North Carolina State University Graphics, 1985. v. 1, cap. 8, p. 95-112.

ESBENSHADE, P. R.; TRIANTAPHYLOU, A. C. Use of enzyme phenotypes for identification of Meloidogyne species. Journal of Nematology. Bethesda, v. 17, n. 1, p. 6-20, 1985.

ESBENSHADE, P. R.; TRIANTAPHYLOU, A. C. Isozyme phenotypes for the identification of Meloidogyne species. Journal of Nematology, Bethesda, v. 22, n. 1, p. 10-15, 1990.

FERREIRA, D. F. Sisvar: a computer statistical analysis system. Ciência e Agrotecnologia, Lavras, v. 35, n. 6, p. 1039-1042, 2011

FISCHER, I. H. et al. Reação de maracujazeiroamarelo ao complexo fusariose-nematoide de galha. Acta Scientiarum Agronomy, Maringá, v. 32, n. 2, p. 223-227, 2010.

GRIFFIN, G. D.; THYR, B. D. Interaction of Meloidogyne hapla and Fusarium oxysporum f. sp. medicaginis on alfafa. Phytopathology, Saint Paul, v. 78, n. 4, p. 421-425, 1988 .

HIRSCHMANN, H. The genus Meloidogyne and morphological characters differentiating its species. In: BARKER, K. R.; CARTER, C. C.; SASSER, J. N. (Eds.). An advanced treatise on Meloidogyne. Raleigh: North Carolina State University Graphics, 1985. v. 2, cap. 2, p. 79-93.

HUSSEY, R. S.; DAVIS, E. L.; BAUM, T. J. Secrets in secretions: genes that control nematode parasitism of plants. Brazilian Journal of Plant Physiology, 
Campos dos Goytacazes, v. 14, n. 3, p. 183-194, 2002.

HWANG, S. C.; KO, W. H. Cavendish banana cultivars resistant to Fusarium Wilt acquired through somaclonal variation in Taiwan. Plant Disease, Saint Paul, v. 88, n. 6, p. 580-588, 2004.

INSTITUTO BRASILEIRO DE GEOGRAFIA E ESTATÍSTICA - IBGE. Levantamento Sistemático da Produção Agrícola. Disponível em: <http:// www.ibge.gov.br/home/>. Acesso em: 08 ago. 2016.

JENKINS, W. R. A rapid centrifugal flotation technique for separating nematodes from soil. Plant Disease Reporter, Beltsville, v. 48, n. 9, p. 692, 1964.

JONES, D. R. Diseases of Banana, Abacá and Enset. Wallingford, UK: CABI Publishing, 2000. $544 \mathrm{p}$.

KNOGGE, W. Fungal infection of plants. The Plant Cell, Los Angeles, v. 8, n. 10, p. 1711-1722, 1996.

KUNIEDA DE ALONSO, S. et al. Análise de isoenzimas para identificação de espécies de Meloidogyne. Fitopatologia Brasileira, Brasília, v. 20, n. 1, p. 20-23, 1995.

MCKINNEY, R. H. Influence of soil temperature and moisture on infection of wheat seedlings by Helminthosporium sativum. Journal of Agricultural Research, Washington, v. 26, n. 5, p. 195-217, 1923.

MOURA, R. M.; REGIS, E. M. O. Reações de feijoeiro comum (Phaseolus vulgaris) em relação ao parasitismo de Meloidogyne javanica e M. incognita (Nematoda: Heteroderidae). Nematologia Brasileira, Piracicaba, v. 11, s/n., p. 215-225, 1987.

OOSTENBRINK, M. Major characteristics of the relation between nematodes and plants. Mededlingen Landbouwhogeschool, Wageningen, v. 66, s/n., p. 3-46, 1966.

PLOETZ, R. C. Management of Fusarium wilt of banana: A review with special reference to tropical race 4. Crop Protection, Lincoln, p. 1-9, 2015.

PLOETZ, R. C.; PEGG, K. G. Fusarium wilt. In: JONES, D. R. (Eds.). Diseases of Banana, Abacá and Enset. Wallingford, UK: CABI Publishing, 2000. p. 143-159.

RIBEIRO, R. C. F. et al. Rizobactérias no controle de Meloidogyne javanica e mal-do-Panamá em bananeira. Nematropica, Jackson, v. 42, n. 2, p. 218 $-226,2012$
SILVA, G. S.; PEREIRA, A. L. Efeito da incorporação de folhas de nim ao solo sobre o complexo Fusarium x Meloidogyne em quiabeiro. Summa Phytopathologica, Botucatu, v. 34, n. 4, p. 368-370, 2008.

SIMÃO, G. et al. Reação de cultivares e linhagens de feijoeiro em relação a Meloidogyne javanica e Fusarium oxysporum f. sp. phaseoli. Ciência Rural, Santa Maria, v. 40, n. 5, p. 1003-1008, 2010.

STOVER, R. H.; BUDDENHAGEN, I. W. Banana breeding: Polyploidy, disease resistance and productivity. Fruits, Leuven, v. 41, n. 3, p. 175-191, 1986.

TENENTE, R. C. et al. Reaction of Different Banana (Musa spp.) Cultivars to Meloidogyne incognita Races 1 and 4. Nematologia Brasileira, Brasília, v. 32 , n. 4, p. 285-293, 2008 